\title{
PERLINDUNGAN HUKUM BAGI PELAKU USAHA ONLINE JIKA TERJADI WANPRESTASI YANG DILAKUKAN OLEH PEMBERI JASA ENDORSE
}

\author{
I Putu Dipta Indrayana, I Nyoman Putu Budiartha, Ni Made Jaya Senastri \\ Fakultas Hukum Universitas Warmadewa, Denpasar-Bali, Indonesia \\ diptaindrayana50@gmail.com, budiarthaputu59@gmail.com, nimadejayasenastri@gmail.com
}

\begin{abstract}
Abstrak
Internet dan jejaring sosial media juga dimanfaatkan sebagai sarana pengembangan ekonomi melalui bisnis bagi masyarakat. Pengembangan bisnis dilakukan oleh pelaku usaha dengan cara endorsement, yang dimana dalam endorsement tersebut terdapat perjanjian kerjasama antar pelaku usaha dengan pemberi jasa endorse. Dalam kerjasama tersebut seringkali terjadi wanprestasi yang dilakukan oleh pemberi jasa endorse. Penelitian ini bertujuan untuk menganalisis bentuk perlindungan bagi pelaku usaha online jika terjadi wanprestasi yang dilakukan oleh pemberi jasa endorse dan menganalisis upaya hukum penyelesaian wanprestasi yang dilakukan oleh pemberi jasa endorse terhadap pelaku usaha online. Metode penelitian dalam tulisan adalah penelitian hukum normatif dan empiris. Dengan pendekatan perundang-undangan, pendekatan secara fakta dan pendekatan kasus. Data primer dan sekunder diperoleh melalui observasi dan wawancara. Setelah data terkumpul, selanjutnya dianalisis dengan analisis kualitatif deskriptif. Hasil penelitian menunjukkan bahwa bentuk perlindungan bagi pelaku usaha online apabila terjadi wanprestasi oleh pemberi jasa endorse dilakukan dengan upaya preventif dan represif, cara penyelesaian masalahnya dilakukan dengan melayangkan somasi atau peringatan sebanyak tiga kali kepada pemberi jasa endorse, dan apabila pihak pemberi jasa endorse tidak memiliki itikad baik, maka penyelesaiannya bisa dilakukan melalui jalur litigasi atau peradilan.
\end{abstract}

Kata Kunci : Pelaku Usaha Online, Pemberi Jasa Endorse, Wanprestasi.

\begin{abstract}
The internet and social media networks are also used as a means of economic development through business for the community. Business development is carried out by business actors by means of endorsements, where in the endorsement there is a Cooperation agreement between business actors and endorsement service providers. In this cooperation, there are often defaults made by endorse service providers. In this regard, two problem formulations can be formulated, namely: What is the form of protection for online business actors in the event of default by endorsement service providers and how the legal remedies for default settlement made by endorsement service providers against online business actors. The research method in writing is normative and empirical law research. With a statutory approach, a factual approach and a case approach. This research concludes that the form of protection for online business actors in the event of default by endorse service providers is carried out by preventive and repressive measures, the way to solve the problem is done by sending three subpoena or warning to the endorse service provider, and if the endorse service provider does not have in good faith, then the settlement can be done through litigation or court.
\end{abstract}

Keywords: Online Business Actors, Endorsement Service Providers, Default

\section{PENDAHULUAN}

Internet merupakan salah satu tanda dari masuknya globalisasi. Internet menyediakan jejaring sosial media yang memungkinkan terhubung atau terkoneksinya masyarakat dari seluruh belahan dunia tanpa adanya batas (Puspita, 2015). Globalisasi juga berdampak bagi kehidupan generasi muda, yang dimana banyak generasi muda yang tertarik dengan kebiasaan dari negara lain yang sebenarnya tidak sesuai dengan adat istiadat dari negara kita. Alat telekomunikasi sekarang telah menyediakan jasa internet di dalamnya yang dimana rata-rata dari pengguna alat telekomunikasi tersebut memiliki jejaring sosial media seperti, facebook, twitter, Instagram dan lain sebagainya. Perkembangan internet dan jejaring sosial media saat ini tidak hanya digunakan sebagai sarana komunikasi, melainkan juga digunakan sebagai sarana penunjang kegiatan masyarakat, baik dibidang politik, sosial, budaya maupun pengembangan ekonomi dan bisnis (Khatimah, 2018). 
Dalam perkembangan ekonomi internet banyak digunakan sebagai sarana dalam berbisnis dalam memasarkan produk dan melakukan transaksi jual beli. Kegiatan perdagangan atau bisnis yang menggunakan internet dan jejaring sosial media dikenal dengan istilah e-commerce. Pengertian dari ecommerce itu sendiri adalah proses jual beli barang yang dilakukan melalui internet (Maulana et al., 2015). Jual beli yang dilakukan secara online dapat mengefektifkan waktu, sehingga memudahkan seseorang untuk melakukan transaksi jual beli dengan siapapun, dimanapun dan kapanpun. Kegiatan jual beli secara online atau e-commerce pada dasarnya tetap memiliki dasar-dasar hukum seperti aktivitas perdagangan pada umumnya, namun pengaturannya lebih dikhususkan mengingat adanya peranan media internet dan alat-alat elektronik dalam proses jual beli tersebut (Ramli, 2004). Perdagangan online atau yang dikenal dengan e-commerce memiliki persaingan yang ketat antar sesama pelaku usahanya, persaingan yang ketat tersebut menyebabkan pelaku usaha online membutuhkan orang untuk mempromosikan produk atau jasa yang pelaku usaha tawarkan. Salah satu upaya promosi yang dilakukan oleh pelaku usaha adalah endorsement atau yang lebih dikenal dengan endorse.

Penggunaan jasa endorse bagi pelaku usaha online didasari oleh perjanjian antara pelaku usaha online dengan pihak pemberi jasa endorse tersebut. Prakteknya, pelaku usaha online akan memberikan tawaran untuk mempromosikan produknya melalui jejaring sosial media dari si pemberi jasa endorse. Setelah diberikan tawaran, pihak pemberi jasa endorse dapat menerima ataupun menolak tawaran tersebut, pemberi jasa endorse juga umumnya memberikan persyaratan produk atau ketentuan-ketentuan lainnya yang harus disiapkan oleh pelaku usaha online. Setelah kedua belah pihak, baik itu pelaku usaha online dan pemberi jasa endorse telah sepakat, maka disana akan timbul hak dan kewajiban bagi pelaku usaha online dan pemberi jasa endorse yang harus dipenuhi. Tercapainya kesepakatan akan ditandai dengan dikirimnya produk yang akan di endorse dari pelaku usaha online ke pihak pemberi jasa endorse. Selanjutnya pemberi jasa endorse akan mengunggah foto atau videonya yang menggunakan produk dari si pelaku usaha online dan akan diunggah ke jejaring sosial media si pemberi jasa endorse.

Kesepakatan yang terjadi antara pelaku usaha online dengan pihak pemberi jasa endorse tersebut terjadi di percakapan dalam telepon seluler, hal tersebut menimbulkan persoalan yang berkaitan dengan kepastian hukum bagi pelaku usaha online jika pemberi jasa endorse melakukan wanprestasi. Kitab Undang-undang Hukum Perdata pasal 1313 di dalamnya menjelaskan mengenai keabsahan suatu perjanjian, yang dimana perjanjian tersebut dilakukan secara tertulis dan dihadiri oleh kedua belah pihak yang sepakat atas pembuatan perjanjian tersebut (Sudarto, 1990). Perjanjian mengenai endorse tidak diatur dalam Kitab Undang-undang Hukum Perdata, tetapi perjanjian endorse ini merupakan bagian dari perkembangan teknologi dalam terjadinya suatu perikatan atau perjanjian antara masyarakat.

Pesatnya kemajuan teknologi menimbulkan terjadinya variasi dalam penggunaannya, sehingga banyak ditemukan perbuatan hukum yang mengakibatkan timbulnya hak dan kewajiban bagi para pihak dan dilakukan dengan memanfaatkan perkembangan teknologi. Hal ini mengakibatkan terjadinya suatu perjanjian antara kedua belah pihaknya tidak berada dalam satu tempat. Perjanjian seperti ini menimbulkan permasalahan mengenai risiko akan jaminan dan risiko akan beban yang dibebankan kepada salah satu pihak yaitu pelaku usaha online sebagai pengguna jasa endorse.

Perjanjian yang telah disepakati antara pelaku usaha online dan pihak pemberi jasa endorse seharusnya dilaksanakan sesuai dengan apa yang telah disepakati dalam media percakapan online tersebut, yang seharusnya kedua belah pihak memndapat keuntungan dari kerjasama tersebut. Tapi dalam praktiknya pihak pemberi jasa endorse seringkali melakukan wanprestasi atas perjanjian yang telah disepakati dengan pelaku usaha online.

Persyaratan Kerjasama antara pelaku usaha online dengan pemberi jasa endorse dalam praktiknya dominan ditentukan oleh pihak pemberi jasa endorse secara sepihak, sedangkan pelaku usaha online sebagai pengguna jasa endorse tersebut hanya dapat menyetujui atau menolak ketentuan Kerjasama yang diajukan oleh pihak pemberi jasa endorse. Oleh karena hal tersebut, pelaku usaha online pada perjanjian kerjasama endorse memiliki posisi yang lemah dan karena itu diperlukan adanya perlindungan hukum bagi pelaku usaha online atas Kerjasama endorsement. Menurut (Rahmani, 2018) Transaksi dan perdagangan yang dilakukan melalui media elektronik cenderung menimbulkan wanprestasi dimana perjanjian kedua belah pihak kadang terlalaikan 
karena tidak ada tatap muka. Pengaturan e-commerce internasional sesuai diatur pada Pasal 18 Ayat (4) dari UU ITE dan Pengadilan Negeri memiliki peran sebagai institusi utama dan pelengkap dalam penyelesaian sengketa transaksi elektronik internasional (Ayu,2018). Selanjutnaya penelitian lain mengungkapkan bahwa jika terjadi wanprestasi perdagangan lewat media elektronik bisa diselesaikan dengan cara hukum perefentif dan represtif (Siska et al., 2019). Sekalipun sudah banyak penelitian terdahulu terkait masalah ini, namun sampai sekarang kasus wanprestasi selalau terjadi oleh karena itu penelitian ini dakukan dengan tujuan menganalisis bentuk perlindungan bagi pelaku usaha online jika terjadi wanprestasi yang dilakukan oleh pemberi jasa endorse dan menganalisis upaya hukum penyelesaian wanprestasi yang dilakukan oleh pemberi jasa endorse terhadap pelaku usaha online

\section{METODE PENELITIAN}

Penelitian ini didesain menggunakan penelitian hukum secara normatif dan penelitian hukum secara empiris (Soekanto, 2007). Penelitian empiris adalah penelitian yang didasari pada pengalaman dan pengamatan yang dilakukan melalui wawancara dengan informan yang terkait dan dilaksanakan langsung dilapangan. Teori hukum kontemplatif yang merupakan gejala umum yang ditimbulkan dari hukum positif yang tujuan nya teoritik dan kebenarannya dianut secara pragmatik yang kegunaannya mengacu pada perbaikan praktik hukum. Sumber data yang digunakan adalah bahan hukum primer dan bahan hukum sekunder. Bahan hukum primer didapat melalui studi lapangan dengan menggunakan tahapan observasi dan wawancara kepada informan atau narasumber yang memiliki kecakapan mengenai teman penulisan ini. Bahan sekunder didapat melalui Undang-undang dan beberapa bahan tulisan hukum yang memiliki tema yang sama dengan penulisan ini. Bahan-bahan hukum yang didapat kemudian dianalisis menggunakan teknik deskriptif kualitatif, yang dimana teknik ini memberikan gambaran mengenai tema tulisan ini dengan kata-kata atau kalimat yang dipisah menurut ketegori untuk memperoleh kesimpulan.

\section{HASIL DAN PEMBAHASAN}

\section{Perlindungan Hukum Bagi Pelaku Online dalam Hal Terjadi Wanprestasi yang Dilakukan oleh Pemberi Jasa Endorse}

Tujuan dari perjanjian jual beli adalah untuk mengikat antara penjual dan pembeli untuk melaksanakan dan memperoleh prestasi. Prestasi itu sendiri memiliki arti yaitu sebagai kewajiban yang harus dipenuhi oleh debitur dalam suatu perjanjian atau perikatan, dimana prestasi tersebut dapat diberikan sesuatu dan tidak berbuat sesuatu (Abdulkadir, 1990). Dalam suatu perjanjian seringkali terjadi persoalan yang menyangkut antar kedua belah pihak yang terlibat di dalamnya, seperti pengingkaran atau tidak dipenuhi kewajiban yang dilakukan oleh pihak debitur kepada pihak kreditur. Dalam hukum perdata, prestasi adalah pihak yang memenuhi janji sesuai dengan perjanjian dan wan prestasi adalah pihak yang mengkihari pemenuhan janji dalam suatu perjanjian.

Perjanjian menerbitkan suatu perikatan antara dua belah pihak yang membuatnya. Bentuk dari perjanjian itu sendiri adalah rangkaian dari kata yang di dalamnya mengandung janji-janji atas kesanggupan yang diucapkan atau ditulis kan (Subekti, 2002). Perjanjian endorsement itu sendiri dapat berjalan dengan baik apabila para pihak yang terlibat di dalamnya telah menyetujui isi dari perjanjian endorsement tersebut, mengenai janji-janji dan kewajiban para pihak, seperti yang telah diperjanjikan tanpa adanya salah satu pihak yang di rugikan dalam perjanjian endorsement tersebut.

Wanprestasi adalah tindakan tidak memenuhi kewajiban yang telah disepakati dalam suatu perikatan baik itu perikatan yang timbul karena suatu perjanjian atau yang timbul dari UndangUndang. Wanprestasi pada umumnya berbeda dengan tindakan melawan hukum. Walaupun jika dilihat secara umum, banyak yang menganggap wanprestasi adalah perbuatan yang melaan hukum, karena tidak dipenuhinya kewajiban oleh debitur kepada kreditur. Tindakan wanprestasti timbul dari suatu persetujuan atas suatu perjanjian, sedangkan perbuatan melawan hukum adalah perbuatan yang timbul dari Undang-undang. Pihak pemberi jasa endorse dapat dikatakan melakukan wanprestasi apabila dilihat dari tidak terpenuhinya kewajiban yang telah dijanjikan kepada pihak pelaku usaha online.

Selain syarat dari sah nya suatu perjanjian sesuai dengan yang diatur dalam pasal 1320 KUHPerdata, dalam pelaksanaannya perjanjian juga harus memperhatikan serta menerapkan asas-asas 
dalam hukum perikatan. Didalam hukum perikatan dikenal beberapa asas-asas hukum, yaitu: asa kebebasan berkontrak, asas itikad baik, asas pacta sun servanda, asas konsensuil dan asas berlakunya suatu perjanjian.

Berkaitan dengan perlindungan konsumen, dikarenakan jasa endorsement ini menyinggung kepentingan konsumen, perjanjian dan penggunaan media elektronik atau jejaring sosial media maka berkaitan dengan pelaku usaha online dan beberapa peraturan perundang-undangan yang mengatur mengenai perlindungan konsumen dan UU No 8 Thn 1999 Tentang Transaksi Elektronik. Perlindungan hukum adalah segala upaya atas pemenuhan hak dan pemberian bantuan atas rasa aman kepada saksi atau korban, perlindungan hukum bagi korban kejahatan sebagai bagian dari perlindungan bagi masyarakat yang dapat diberikan dalam berbagai bentuk. Bantuan hukum. Perjanjian endorsement antara pelaku usaha online dan pemberi jasa endorse merupakan bagian dari perkembangan teknologi. Perjanjian endorsement akan memberikan tanggungjawab kepada masingmasing pihak baik itu pelaku usaha online atau pemberi jasa endorse. Selanjutnya kedua belah pihak berhak atas perlindungan hukum, perlindungan hukum dapat berupa preventif atau perlindungan yang diberikan sebelum terjadinya sengketa dan perlindungan hukum secara represif atau perlindungan yang diberikan setelah terjadinya sengketa. Berdasarkan uraian di atas, maka apabila pihak pemberi jasa endorse melakukan wanprestasi, maka pemberi jasa endorse tersebut harus siap bertanggungjawab atas ganti rugi dan sanksi-sanksi dari perbuatannya yang dianggap telah merugikan pihak pelaku usaha online.

\section{Upaya Hukum Penyelesaian Wanprestasi yang Diberikan oleh Pemberi Jasa Endorse Bagi Pelaku Usaha Online}

Akibat yang ditimbulkan apabila debitur melakukan wanprestasi, yaitu membayar kerugian yang ditimbulkan oleh debitur kepada kreditur atas wanprestasi tersebut, pembatalan atas perjanjian atau yang lebih dikenal dengan pemecahan perjanjian, peralihan risiko adalah kewajiban untuk memikul kerugian apabila terjadi peristiwa wanprestasi dan membayar biaya perkara apabila permasalah wanprestasi tersebut sampai ke tahapan pengadilan (Harahap, 1989). Jika terjadi wanprestasi oleh salah satu pihak dalam suatu perjanjian, maka pada umumnya langkah yang dapat diambil oleh pihak yang dirugikan atas wanprestasi tersebut adalah dengan memberikan peringatan sebanyak tiga kali dan berharap agar pihak terkait memenuhi prestasinya (Sarwono, 2011). Pelaku usaha online memberikan surat secara tertulis atau somasi kepada pihak pemberi jasa endorse dan berharap adanya itikad baik dari pihak pemberi endorse selaku pihak yang melakukan wanprestasi.

Pemberian somasi tersebut kedalam penyelesaian sengketa non litigasi sesuai dengan yang tertuang dalam pasal 1 UU No. 30 Tahun 1999 Tentang Penyelesaian Sengketa Atau Perkara Diluar Pengadilan dengan cara alternatif. Penyelesaian ini juga dapat dilakukan dengan cara mediasi, konsiliasi, konsultasi, negosiasi dan penilaian dari ahli atas permasalah tersebut. Konsultasi adalah upaya yang bersifat personal yang dilakukan dengan cara klien dengan pihak konsultan, dimana pihak konsultan tersebut memberikan pendapatnya atas sengketa tersebut dengan kebutuhan dan keperluan kliennya. Negosiasi adalah penyelesaian dari suatu sengketa yang dilakukan dengan damai melalui perundingan antara pihak-pihak yang terlibat didalamnya atau pihak-pihak yang bersengketa. Negosiasi adanya penyelesaian yang dilakukan tanpa melalui proses pengadilan dalam proses mencapai kesepakatan antara kedua belah pihak.

Prinsip-prinsip dari perlindungan konsumen di Indonesia, mediasi merupakan proses penyelesaian sengketa yang dilakukan diluar pengadilan dengan fleksibel dan tidak melibatkan pihak tertentu atau pihak netral, yang memudahkan negosiasi antara kedua belah pihak dalam menemukan kesepakatan atas penyelesaian sengketa. Konsolidasi merupakan upaya yang dilakukan dengan cara mempertemukan keinginan-keinginan dari kedua belah pihak yang bersengketa guna menyelesaikan sengketa dan mencapai kesepakatan guna menyelesaikan sengketa secara kekeluargaan. Konsolidasi ini bertujuan agar kedua belah pihak menemukan kesepakatan atas perselisihan diantara mereka.

Penyelesaian sengketa umumnya dapat diselesaikan oleh para pihak dengan itikad baik dan mengesampingkan penyelesaian melalui jalur litigasi atau jalur hukum. Tetapi, dalam praktiknya pihak pemberi jasa endorse tidak menunjukan itikad baik dalam penyelesaian sengketa. Atas hal tersebut pelaku usaha online dapat melakukan atau mengajukan tuntutan berupa: pembatas atas perjanjian, pemenuhan atas perjanjian, pembatalan perjanjian yang disertai dengan ganti rugi, pembayaran ganti rugi, pemenuhan atas perjanjian dan ganti rugi kerugian. Pihak pelaku usaha online 
dapat meminta pertanggungjawaban kepada pihak penyedia jasa endorse atas tindakan wanprestasi yang telah dilakukannya dalam transaksi elektronik atau dalam transaksi yang melalui internet dan jejaring sosial media. Merujuk kepada bunyi pasal 7 huruf g UUPK yang mana menjelaskan pihak penyedia jasa endorse wajib memberikan kondensasi kepada pelaku usaha online apabila terjadi ketidaksesuaian atas perjanjian yang telah kedua belah pihak sepakat.

Menurut pihak pelaku usaha online yaitu@ @ thismayshop_saudari Maysani, wanprestasi yang dilakukan oleh pihak pemberi atau penyedia jasa endorse harus secepat mungkin diselesaikan baik itu dalam tuntutan ganti rugi, maupun pemenuhan prestasi. Karena barang seperti baju yang diberikan akan mengalami penurunan harga setiap bulannya, penurunan harga tersebut dikarenakan oleh tren busana yang berkembang sangat pesat setiap bulannya. Tindakan litigasi atau hukum melalui peradilan belum pernah dilakukan oleh pihak Maysani selaku pelaku usaha online karena beliau masih berharap pada itikad baik dari pemberi atau penyedia jasa endorse.

\section{SIMPULAN DAN SARAN}

\section{Simpulan}

Dari hasil analisis data, dapat disimpulkan bahwa perlindungan hukum bagi pelaku usaha online apabila terjadi wanprestasi yang dilakukan oleh pihak pemberi atau penyedia jasa endorse melalui dua bentuk perlindungan hukum yaitu perlindungan hukum secara preventif dan perlindungan hukum secara represif. Cara penyelesaian sengketa wanprestasi yang dilakukan oleh pihak pemberi atau penyedia jasa endorse adalah dengan memberikan somasi sebanyak 3 kali dan berharap pemberi dan penyedia jasa endorse memiliki itikad baik atas pemenuhan prestasi kepada pihak pelaku usaha online. Namun, apabila somasi tersebut tidak direspon dan pemberi atau penyedia jasa endorse tidak menunjukan itikad baiknya, maka dapat dilakukan dengan penyelesaian secara nonlitigasi seperti mediasi, konsiliasi, konsolidasi dan negosiasi

\section{Saran}

Sesuai simpulan penelitan di atas, adapun saran yang diberikan yaitu kepada pelaku usaha online supaya bersikap lebih tegas dan hati-hati kepada pemberi atau penyedia jasa endorse yang melakukan wanprestasi, agar barang jual dapat dikembalikan dan dijual kembali sebelum peminatnya menurun. Mengingat trend fashion memiliki perubahan tren yang cukup cepat setiap bulannya. Selanjutnya diharapkan kepada penegak hukum untuk membuat suatu aturan atau kebijakan yang tegas untuk pelaku wanprestasi sehingga hal tersebut tidak terulang lagi

\section{DAFTAR PUSTAKA}

Abdulkadir. (1990). Hukum Perikatan. PT Citra Aditya Bhakt. Bandung.

Harahap, M. Y. (1989). Kedudukan Kewenangan dan Acara Peradilan Agama. Sinar Grafika.

Khatimah, H. (2018). Posisi dan Peran Media dalam Kehidupan Masyarakat. Jurnal Tasamuh, 16(1), $119-138$.

Maulana, S. M., Susilo, H., \& Riyadi. (2015). Implementasi E-Commerce Sebagai Media Penjualan Online. Jurnal Administrasi Bisnis, 29(1), 1-9.

Puspita, Y. (2015). Pemanfaatan New Media dalam Memudahkan Komunikasi dan Transaksi Pelacur Gay. Jurnal Pekomnas, 18(3), 203-212.

Rahmani, I. (2018). Perlindungan Hukum kepada Pembeli dalam Kepailitan Pengembang (Developer) Rumah Susun. Jurnal Hukum Bisnis Bonum Commune, 1(1), 73-88.

Ramli, A. M. (2004). Cyber Law dan HAKI dalam Sistem Hukum Indonesia. Refika Aditama. Jakarta. Sarwono. (2011). Hukum Acara Perdata Teori dan Praktik. Sinar Grafika. Jakarta.

Siska, S. N. L. P., Putra, A. I. B., \& Wiratni, D. A. . S. (2019). Perlindungan Hukum terhadap Pelaku Usaha Online Shop Apabila Terjadi Wanprestasi Yang Dilakukan oleh Pemberi Jasa Endorse di Kota Denpasar. Journal Ilmu Hukum, 7(4), 1-19.

Soekanto, S. (2007). Faktor-Faktor yang Mempengaruhi Penegakan Hukum. PT Raja Grafindo Persada.

Subekti. (2002). Hukum Perjanjian. Intermasa.

Sudarto. (1990). Hukum Pidana Islam. Semarang: Yayasan Sudarto. 